\title{
«Slike mødre»: Barnevernets stigmatisering av sårbare familier i dagens Russland
}

\author{
Trine Skogset Ofitserova
}

Master i russlandsstudier

\begin{abstract}
That kind of mother': Stigmatisation by the Russian child protection services

How does stigma influence the extent to which the child protection services in Russia undertake preventative work with vulnerable families in order to avoid taking the child out the family? Based on an analysis of previous research and my own fieldwork from St. Petersburg and Moscow, I note the gap between expectations towards vulnerable families, and their actual living conditions and potential for meeting these expectations. This gap results in a stigmatising categorisation of families who find themselves marginalised as neblagopolutsjnye - socially disadvantaged. Although Russia's officially 'family-oriented' child protection system is expected to base its work on objective methods, stigmatisation influences the decisions of social workers, making the system risk-oriented in practice. This is due to little or inadequate specialised education among social workers, resulting in the strong presence of the human factor: subjective, non-professional evaluations are made. With scant intersectional cooperation among state actors, there is little space to counteract or modify subjective evaluations. Thus, stigmatisation serves to limit the extent to which vulnerable families in Russia receive help, thus creating and upholding 'social orphanhood'.
\end{abstract}

Keywords: Russia, stigmatization, social welfare, child protection, social disadvantage

Under en konferanse rettet mot russiske foreldre hevdet Vladimir Putin (2013) at man ikke kan måle barnevernets effektivitet i antall omsorgsovertakelser, men at den må måles etter hvor godt barnevernet lykkes med å fjerne årsakene til at ulike familier har det vanskelig. Siden siste halvdel av 2000-tallet har russisk myndigheter fokusert stadig mer på den tradisjonelle familiens plass i det russiske samfunnet (Bindman et al., 2018, s. 211; Höjdestrand, 2016, s. 830). Spesielt Dima Jakovlev-saken fra 2008, der en russisk gutt døde som følge av omsorgssvikt fra sine amerikanske adoptivforeldre, førte til at myndighetene så seg nødt til i større grad å ta tak i det nasjonale barnevernssystemet, etter at de forbød adopsion av russiske barn til USA (Bindman

Kontaktinformasjon:Trine Skogset Ofitserova, e-post: trine_t_skogset@hotmail.com 
et al., 2018, s. 211; Schmidt \& Schurko, 2014, s. 453). Et behov for å reformere et kostbart institusjonsbasert system meldte seg, og dette, i tillegg til en demografisk nedgang, førte til et økt politisk fokus på å ivareta den russiske familien og jobbe forebyggende med sårbare familier giennom det som kan kalles et paradigmeskifte innen russisk barnevern (Bindman et al., 2018, s. 211; Kulmala et al., 2017, 2020).

Flere forskere (f.eks. Bindman et al., 2018; Birjukova \& Siniavskaia, 2017; Johnson et al., 2014) peker på en stor ideologisk og politisk fremgang i form av reformer som anerkjenner viktigheten av en familiefokusert barnevernsstrategi. Samtidig trekkes det frem flere svakheter i dens implementering i møte med enkeltfamilier, deriblant forekomsten av stigmatisering på bakgrunn av familienes økonomiske og sosiale sårbarhet (Jäppinen, 2020; Rockhill, 2010; Sidorova \& Rockhill, 2016). Forskningen har pekt på en avstand mellom vedtak av politiske reformer og det at paradigmeskiftet faktisk forankres ideologisk i de menneskene som i praksis skal gjennomføre dem. Derfor skal jeg i denne artikkelen se nærmere på hvordan sosialt stigma kommer til syne blant ansatte i barnevernet og det russiske velferdssystemet, hvor det kan stamme fra og hva som kan vare medvirkende årsaker til at stigma påvirker implementeringen av det forebyggende arbeid med sårbare familier. Jeg setter tematikken inn $i$ et teoretisk rammeverk rundt negativ og positiv frihet, for å se om noe av årsaken til stigmatiseringen kan ligge i skjæringspunktet mellom forventningene som stilles og premissene som legges for at sårbare familier skal kunne ivareta sine barn på en tilfredsstillende måte.

\section{Liberalisering og deinstitusjonalisering}

Svært mange russiske familier har siden 1990-tallet, etter Sovjetunionens oppløsning, opplevd store økonomiske og sosiale utfordringer (Firsov, 2005, s. 60; Holm-Hansen et al., 2003, s. 28). De hadde gått fra å leve i et sosialistisk system der staten blant annet garanterte befolkningen gratis skolegang og helsetilbud, høy arbeidsdekning og små inntektsforskjeller, til et liberalt markedsbasert system hvor fokuset på økonomisk lønnsomhet ikke lenger kunne forsvare en slik sosial velferd innenfor en stat som slet økonomisk (Cook, 2011, s. 239-40, 2015, s. 2335; Maltseva, 2016, s. 233). Som Tsjernova (2013, s. 76, s. 80) beskriver det, gikk den russiske befolkningen fra et mer eller mindre likestilt og forutsigbart tilbud om sosial støtte, om enn ikke av veldig høy standard, til et markedsstyrt og individualistisk system, hvor de i større grad ble møtt av en forventning om å skulle sørge for sin egen velferd.

Staten kan altså sies å ha vært tett involvert i folks liv under Sovjetunionen i form av en sosial kontrakt basert på gjensidig avhengighet mellom staten som forsørger og en lojal arbeidsytende befolkning. Etter Sovjetunionens fall ble det i stedet innført en slags «vertikal sosial kontrakt», der avstanden mellom staten og folket er større, spesielt hva angår statens sosiale bidrag (Cook \& Dimitrov, 2017, s. 18; Tsjernova, 2012, s. 76). Folket fikk med andre ord større frihet i betydningen mulighet til å ta valg uten innblanding fra andre, men ikke i like stor grad frihet $\mathrm{i}$ 
form av økonomisk spillerom. Dette førte til en stor økning i sosiale problemer som arbeidsledighet, alkoholmisbruk, samlivsbrudd, samt et økt antall aleneforeldre - i all hovedsak alenemødre. Økningen var størst på 1990-tallet, men har også vedvart etter at Putin kom til makten i 2000 (Birjukova et al., 2013; Dementeva, 2016; Maltseva, 2016, s. 232; Mardakhajev, 2005). Mange barn endte dermed opp som sosialt foreldreløse. Dette innebærer at foreldrene er i live, men at de av sosiale grunner ikke er i stand eller villige til å sørge for sine barns beste (FNs barnekonvensjon, 1989; Mardakhajev, 2005, s. 52).

Antallet sosialt foreldreløse barn nådde en topp i 2014 med 726900 hvorav mange var plassert på institusjoner (Birjukova \& Sinjavskaja, 2017, s. 370-371). Statlig institusjonell omsorg har i Russland røtter helt tilbake til 1400-tallet, men fikk en dypere ideologisk forankring under Sovjetunionen. Da var barneinstitusjoner ikke lenger til bare for det store antall foreldreløse barn etter første og andre verdenskrig; døgnåpne barnehager skulle hjelpe sovjetiske arbeidere generelt, og sovjetiske kvinner spesielt, ut i arbeid (Firsov, 2005, s. 140, s. 59-60; Holm-Hansen et al., 2003, s. 31; Kelly, 2007, s. 2; Tsjernova, 2012, s. 75-76). Staten var altså involvert i innbyggernes liv som en del av en slags utvidet familie, som i fellesskap skulle sørge for barns, familiers og ikke minst nasjonens beste. Institusjonell omsorg har dog vist seg å være svært uheldig for foreldreløse barn på barnehjem (Fujimura et al., 2005, s. 72; Petrovskij et al., 2017, s. 389). Ifølge forskningen kan de i sitt voksenliv få problemer med å knytte seg til andre, samt å stole på omverdenen, og således også få vanskeligheter med å bygge sunne relasjoner til andre mennesker. I tillegg kan foreldreløse barn leve med en følelse av at det er "dem mot verden», vise aggressiv oppførsel og mangle selvstendighet og evne til å legge langtidsplaner for sine egne liv siden de har vært vant til å leve innenfor satte institusjonelle rammer (Dementeva, 1992, s. 66-67; Muratkina, 2014, s. 170; Semja, 2009, s. 29-30).

Gitt disse sosiale utfordringene og et økende fokus på familien, har Russland, i likhet med mange andre land, siden 1994/1995 og introduksjonen av det nasjonale programmet Russlands barn, gått aktivt inn for en deinstitusjonalisering av barnevernet. Dette innebærer å hindre at barn havner på institusjoner gjennom forebyggende arbeid og bruk av familielignende omsorgsalternativer (Holm-Hansen et al., 2003; Semja et al., 2016, s. 68, s. 70). Alternativene som ble utviklet utover 2000-tallet var blant annet økt grad av adopsjon og flere verge- og fosterfamilier, men også reorganisering av eksisterende institusjoner slik at de kunne minne mer om et familiehjem (Holm-Hansen et al., 2003).

I 2012, ved innføringen av Den russiske nasjonale strategi for barns interesser 20122017, ble det videre satt fokus på at tjenestene som ivaretok barns interesser også måtte jobbe med biologiske foreldre. Samtidig ble viktigheten av samarbeid mellom de departementer og instanser som jobber innenfor barnevernsfeltet, inkludert NGO-er understreket. (Bindman et al., 2019, s. 208, s. 211-212; Semja \& Telitsina, 2016, s. 169; Ukaz Prezidenta, 2012). Senere ble det blant annet innført tiltak som skulle forene de instanser som jobber med barnevern, slik at de i større grad kunne 
samarbeide om både å finne familielignende alternativer til foreldreløse barn og å jobbe forebyggende med biologiske familier (Semja et al., 2016, s. 76). Statistikk viser at bruken av familielignende alternativer har økt som følge av reformene, selv om det fremdeles gjenstår flere utfordringer, som å sikre at søsken får leve sammen og at barn med psykiske og fysiske utfordringer får samme behandling som andre barn (Birjukova \& Marakansteva, 2020). Imidlertid har forebyggende arbeid med sårbare familier ikke blitt iverksatt og spørsmålet jeg stiller, er om sosialarbeidernes holdninger kan påvirke dette.

\section{Metodisk rammeverk}

Temaet russisk barnevern har interessert meg siden jeg som ungdom besøkte et barnehjem i Russland på begynnelsen av 2000-tallet. Gjennom å jobbe som frivillig på barnehjemmet i ett år, og etter det å følge de foreldreløse barna på deres vei mot, og inn i, voksenlivet, har jeg blitt interessert i deinstitusjonaliseringsprosessen som har foregått siden 2010-tallet, og spesielt arbeidet som gjøres for å forebygge sosial foreldreløshet. Etter å ha bodd til sammen 7 år i Russland, hvorav to av dem som småbarnsmor, har jeg på nært hold møtt mange negative holdninger overfor marginaliserte mennesker. Som frivillig ved barnehjemmet møtte jeg for eksempel til stadighet russere som ikke kunne forstå hvorfor jeg ville bruke av min tid til å forbedre tilværelsen til mennesker som var av «lavere rang» og «uansett var dømt til et miserabelt liv». Som norsk mor i Russland ble jeg fra omgangskrets, helsevesen, så vel som tilfeldig forbipasserende, ofte minnet på hvilke klare forventninger om hvordan en god mor skal være som finnes i det russiske samfunnet. Dette gjorde meg oppmerksom på hvordan mennesker som virkelig skiller seg fra normen på ulike måter kan bli møtt. Dette samlede erfaringsgrunnlaget har ført meg til det forskningsprosjektet som ligger til grunn for denne artikkelen.

Artikkelen baserer seg på internasjonal forskning og litteratur om barnevern og sosial velferd i Russland de senere årene, men også på data innsamlet under et feltarbeid vinteren 2019 i Moskva og St. Petersburg. Siden problemstillingen kan kategoriseres som konstaterende (Kalleberg et al., 2009, s. 47) og altså søker å beskrive en virkelighet, er det hensiktsmessig å gjennomføre dybdeintervjuer for å skaffe førstehåndsinformasjon fra personer som i det daglige har en relasjon til barnevernet i Russland. Målet var å gjennomføre intervjuer med representanter fra barnevernet, sårbare familier og representanter fra NGO-er innen barnevernsfeltet. Av grunner som streng kontroll og begrenset tilgang til sårbar informasjon for utenlandske borgere fikk jeg ikke adgang til de to første gruppene. Den siste gruppen representerer likevel en svært relevant informasjonskilde, som i mangel på et fullverdig strategisk utvalg, og til tross for sine begrensninger, gir et nyansert datagrunnlag (Thagaard, 2003, s. 54). NGO-er har spilt, og spiller, en sentral rolle i de endringer som russisk barnevern og sosial velferd faktisk har gått gjennom de siste årene. På den ene siden jobber de på bakkenivå med foreldreløse 
barn som befinner seg i alternativ omsorg og driver forebyggende arbeid rettet mot sårbare familier. På den andre siden har de, basert på sine praktiske erfaringer, hatt stor innflytelse på de nasjonale og regionale reformene som ble initiert på 2010-tallet (Bindman et al., 2018; Cook, 2015, s. 2341). For å bevare det nøytrale og upartiske perspektivet som en konstaterende innstilling krever og kompensere for min manglende tilgang til sentrale utvalg, har jeg også intervjuet to forskere på barnevernsfeltet ved Den høyere skolen for økonomi i Moskva, hvorav én er forsker ved Institutt for sosialpolitikk og den andre er seniorforsker ved Senter for forskning på sivilsamfunn og frivillig sektor. I tillegg har jeg intervjuet en representant for Barneombudet i St. Petersburg, samt lagt vekt på komplementerende litteratur (Fog, 1996, s. 218-219; Kalleberg et al., 2009, s. 48).

Jeg utførte til sammen elleve dybdeintervjuer i Moskva og St. Petersburg. Samtlige informanter har mange års erfaring både på bakke- og ledernivå innenfor arbeid med foreldreløse barn og sårbare familier. Her er utfyllende informasjon om utvalget:

1. Moskva, 04.03.2019: Aleksandra Telitsina, forsker ved Den høyere skolen for økonomi i Moskva.

2. St. Petersburg, 07.03.2019: Svetlana Birjukova, forsker ved Den høyere skolen for økonomi i Moskva.

3. Moskva, 27.02.2019: Aleksandr Gezalov fra Den hellige Tikhon sosialsenter (Sotsialnyj tsentr sviatitelja Tikhona). Han har selv vokst opp på barnehjem og har hele sitt voksne liv jobbet for å hjelpe foreldreløse barn med et særskilt fokus på å jobbe forebyggende med sårbare familier.

4. Moskva, 28.02.2019: Representant for SOS-barnebyers hovedkontor i Moskva.

5. Moskva, 28.02.2019: Representant fra veldedighetsfondet Barndomselven (Reka detstva). Informanten har i over tolv år jobbet for å hjelpe foreldreløse barn.

6. Moskva, 04.03.2019: Jelena Alsjanskaja fra veldedighetsfondet Frivillige hjelper foreldreløse barn (Volontjory $v$ pomosjtsj detjam-sirotam). Hun har i over sytten år jobbet sosialt og politisk for å bedre foreldreløse barns tilværelse, men også med å forebygge sosial foreldreløshet gjennom arbeid med sårbare familier.

7. St. Petersburg, 05.03.2019: To representanter for veldedighetsfondet Partnerskap for hvert barn (Partnjorstvo kazjdomu rebjonku).

8. St. Petersburg, 06.03.2019: To representanter for Barneombudet i St. Petersburg.

9. St. Petersburg, 06.03.2019: To representanter for SOS-barnebyer i St. Petersburg.

10. St. Petersburg, 07.03.2019: To representanter for veldedighetsfondet Et varmt hjem (Teplyj dom).

11. St. Petersburg, 07.03.2019: Representant fra SOS-barnebyer i St. Petersburg. Informanten var byansvarlig for organisasjonens forebyggende arbeid med sårbare familier.

Representantene for Den hellige Tikhon sosialsenter og Frivillige hjelper foreldreløse barn er ansett som offentlige eksperter på barnevernsfeltet i Russland og tar aktivt del blant annet i arbeidsutvalg som forsøker å påvirke politiske beslutninger. Grunnet 
sin offentlige profil er disse navngitt, i tillegg til forskerne, som offentlig har publisert vitenskapelig materiale om temaet. Øvrige informanter er anonymisert av hensyn til personvern. Møtene ble avtalt ved hjelp av snøballmetoden, hvor jeg etter egne undersøkelser startet med å kontakte forskere og eksperter, som så henviste meg videre til andre potensielle informanter (Thagaard, 2003, s. 54). Intervjuene var semistrukturerte, og jeg stilte åpne spørsmål for å gi informantene stor frihet til å forme innholdet i intervjuet. De ble bedt om å fortelle fritt om sitt arbeid og sin organisasjon; hvordan deres arbeid er relatert til sårbare familier; deres samarbeid med barnevernet og sosialkontorer; deres refleksjoner rundt barnevernets forebyggende arbeid med sårbare familier, hvilke utfordringer de ser og årsakene til dette. Intervjuene ble til slutt analysert basert på en temasentrert tilnærming og med induktive koder med utgangspunkt i temaer som ble adressert av informantene (Thaagard, 2003, s. 132, s. 137). Informantene trakk blant annet stigma frem som et sentralt tema, noe jeg så jobbet videre med.

\section{Teoretisk rammeverk}

\section{Det russiske barnevernets ideologiske strategi - et paradigmeskifte}

Barnevern i ulike land kan beskrives ut fra hvilke strategier de baseres på. Barnevernet kan på den ene siden følge en risikoorientert eller serviceorientert strategi. En riksorientert strategi kjennetegnes ved barnevernets innføring av risikofjernende tiltak på et sent stadium, mens en serviceorientert strategi bærer preg av risikoforebyggende og -dempende tiltak som blir satt inn på et tidlig stadium (Krutzinna \& Skivenes, 2020, s. 51). På den andre siden kan barnevernet følge en barnebeskyttelses-, familieorientert eller barnefokusert strategi. En barnebeskyttelsesstrategi søker primært å skjerme barnet fra skade som skyldes familiemedlemmer, mens en familieorientert strategi fokuserer på å overkomme de faktorer i en familie som fører til ulik grad av omsorgssvikt. Den barnefokuserte strategien går på sin side ut på at barnet blir tillagt egne selvstendige rettigheter relatert til staten, i indirekte opposisjon til foreldrene (Gilbert et al., 2011, s. 3, s. 252). En normativ sammenligning av de ulike strategiene er et komplekst spørsmål, avhengig av om man tar utgangspunkt i perspektivet til staten, barnet, foreldrene eller familien som helhet, og samspillet mellom de sistnevnte perspektivene vil variere i samsvar med et lands sosiale, politiske og økonomiske landskap (Gilbert et al., 2011, s. 256). Norge, som følger en barnefokusert og serviceorientert strategi, har eksempelvis ved flere anledninger blitt dømt i Den europeiske menneskerettighetsdomstolen for mangelfull ivaretakelse av foreldrenes perspektiv ved å krenke retten til privat- og familieliv giennom tvangsadopsion (Dahl \& Schmidt, 2020; Gilbert et al., 2011, s. 252). Dette vitner om kompleksiteten i barnevernets valg mellom ulike perspektiver og interesser.

Hvilken retning Russland bør følge, har vært et tema for diskusjon på et politisk nivå så vel som på et folkelig nivå. Spørsmål om det som gjerne kalles «russiske 
konservative familieverdier» settes opp mot både offisiell reformpolitikk og internasjonale krav til implementeringen av FNs barnekonvensjon etter dens ratifisering $\mathrm{i}$ 1990 (Höjdestrand, 2016; Schmidt \& Schurko, 2014, s. 451, s. 453). Diskusjonen foregår også om prinsipper som barns interesser, foreldres interesser, skille mellom den private og offentlige sfære og familiens rettigheter i dette skjæringspunktet (Gilbert et al., 2011; Schmidt \& Schurko, 2014). Man kan likevel si at Russland i dag ligger nærmest en risikoorientert barnebeskyttelsesstrategi, hvor staten på et juridisk grunnlag intervenerer og beskytter barnet mot vold og omsorgssvikt på et relativt sent stadium, uten å samarbeide nevneverdig med den aktuelle familien (Jäppinen, 2020; Sidorova \& Rockhill, 2016, s. 48).

De ovennevnte reformene tilsier imidlertid at det formelt sett tilstrebes en overgang til et familieorientert fokus der man i større grad jobber med familiene for å finne en best mulig løsning for barnet. På den ene siden innebærer dette skiftet å hjelpe barnets biologiske familie i å ivareta det som betraktes som barnets beste (Jäppinen, 2020). Som Stang skriver "har foreldre og barn en felles interesse $i$ at familien som helhet og hvert enkelt familiemedlem fär hjelp til sine felles og separate problemer, herunder at foreldre får hjelp til å klare omsorgsoppgaven bedre» (2007, s. 99). ${ }^{1}$ En familieorientert strategi insinuerer dermed indirekte at det biologiske prinsipp er av verdi i den grad relasjonen mellom barnet og dets biologiske foreldre kan anses som hensiktsmessig for barnet å bevare ved å sette inn hjelpetiltak der det trengs (Stang, 2007, s. 98). På den andre siden innebærer paradigmeskiftet mot en familieorientert strategi deinstitusjonalisering. Selv om man anerkjenner at å ta barnet ut av familien er en risiko som, i den grad det er mulig, bør søkes å forebygges, anses omsorgsovertakelse nødvendig i tilfeller der øvrig hjelp rettet mot den biologiske familien ikke synes hensiktsmessig med tanke på beskyttelsen av barnet (Stang, 2007, s. 98-100). I tilfeller med omsorgsovertakelse innebærer en familieorientert strategi å tilby de barn som er nødt til å forlate sin biologiske familie et familielignende omsorgsalternativ.

Et annet perspektiv relatert til en familieorientert strategi springer ut fra bevegelsen mot konservative familieverdier, som har funnet sted i Russland de senere årene (Höjdestrand, 2016). Innenfor et konservativt verdisystem kan familiens rettigheter tolkes som ensbetydende med foreldres, og man beveger seg bort fra familiefokuset i sin rette og brede betydning, men også fra barnebeskyttelsesstrategien (Gilbert et al., 2011, s. 6). Hvorvidt en konservativ beskyttelse av foreldres interesser gjelder alle samfunnslag, eller kun enkelte, er et annet spørsmål som melder seg. Stigmatisering av familier med sosiale og økonomiske vansker kan tenkes å bidra til at barnevernet ser bort fra både familiens og barnets beste i velstående familier hvor vold og annen omsorgssvikt også forekommer. Den familiefokuserte strategien kan i så måte ses som et retorisk grep, som i praksis skjuler at man på et konservativt

${ }^{1}$ Kursiv gjengitt som i kildeteksten. 
verdigrunnlag ikke ønsker å ta tak i de virkelige problemene som strider mot barns rettigheter $i$ henhold til internasjonale reguleringsmekanismer som FNs barnekonvensjon (Schmidt \& Schurko, 2014, s. 455). Dette skal jeg komme tilbake til, men først skal jeg se på sammenhengen mellom de premisser og forventinger et menneske blir møtt med i et samfunn, og hvordan tvetydighet rundt dette kan føre til stigmatisering.

\section{Grunnlaget for stigmatisering}

Hvordan et individ, eller en familie, er i stand til å leve innenfor et gitt velferdssystem, er tett knyttet til det Isaiah Berlin kaller positiv og negativ frihet. Han definerer negativ frihet som en ramme hvor et menneske kan ta egne valg angående hva hen kan gjøre og være uten innblanding fra andre (Berlin, 1958, s. 7). Likevel finnes det noen begrensninger knyttet til slik frihet, som at for eksempel fattigdom og sosiale forhold påvirker i hvilken grad du faktisk har muligheten til å leve slik du ønsker (Berlin, 1958, s. 9). Dette er tett forbundet med det Berlin kaller positiv frihet, nemlig muligheten til å realisere din frihet (Berlin, 1958, s. 7). Det knyttes en viss grad av relativitet til den positive friheten, gitt at den impliserer at noen har en autoritet til å bestemme hva denne friheten innebærer (Berlin, 1958, s. 17-18). Overført til et nasjonalt plan kan dette implisere at en stat eller en sosial majoritet påberoper seg å ta rasjonelle beslutninger på vegne av mindre rasjonelle eller annerledes borgere, og dermed kvalitativt definerer det livet som borgerne har positiv frihet til å realisere. Dette setter den positive friheten i et relativt og potensielt farlig lys, og illustrerer hvordan andres definisjonsmakt kan gi grobunn for stigmatisering av de som ikke klarer å realisere den forhåndsdefinerte positive friheten.

Ifølge Goffman (2011, s. 9) avgjør ethvert samfunn hvordan man skal dele inn mennesker i kategorier og hvilke egenskaper som definerer tilhørigheten til disse. En diskrediterende egenskap som definerer en tilhørighet til en viss kategori mennesker kan føre til stigma (Goffman, 2011, s. 11). Man kan dele stigma inn i fysiske, karakterbaserte og slektsbetingede svakheter, hvorav stigma relatert til sosiale og økonomiske vansker ofte plasseres i kategorien for karakterbaserte svakheter (Goffman, 2011, s. 12). Spicker (1984, s. 45-46) mener derimot at Goffmans inndeling fokuserer for mye på den stigmatisertes egenskaper, og hevder, gjennom å understreke det relasjonelle aspektet ved stigma, at disse egenskapene ikke trenger å være reelle, men at det er tilstrekkelig at majoriteten antar at de finnes (Hove, 2001, s. 21). De som av ulike grunner antas ikke å mestre å leve slik som det øvrige samfunnet forventer, kan dermed tenkes å bli stigmatisert av den majoriteten som mestrer det. Økonomiske og sosiale vansker blir således en mulig diskrediterende egenskap som definerer tilhørigheten til den kunstige kategorien sårbar og utilpass, uten at hverken sannhetsverdien i denne antakelsen eller årsakene til denne egenskapen blir problematisert. Gitt maktasymmetrien mellom bruker og sosialarbeider kan dermed stigmatisering føre til en kategorisering av verdige og uverdige trengende, noe som igjen kan betinge 
i hvilken grad de trengende får hjelp med sine utfordringer (Gjertsen, 2007, s. 85; Midré, 1995, s. 13; Westby, 2021, s. 272).

Med utgangspunkt $i$ at en offisiell familieorientert strategi i sin brede betydning innebærer at staten skal ta et stort ansvar for barnets grunnleggende sosiale sikkerhetsnett, skal jeg i lys av mitt feltarbeid videre belyse hvordan dette praktiseres i en kontekst av et velferdssystem som er preget av liberalisering og markedsbaserte krefter (Gilbert et al., 2011, s. 6).

\section{Velferd og barnevern i praksis}

Mine informanter fortalte at en dominerende andel av de foreldre som er i kontakt med barnevernet er det man kan kalle økonomisk eller sosialt sårbare, og lever dermed innenfor rammer av begrenset positiv frihet. At denne gruppen mennesker er i barnevernets søkelys er ikke unikt for Russland, og selv Norge, med et høyt ansett velferdssystem og en serviceorientert strategi, opplever det samme (Andenæs, 2004; Westby, 2021). Som nevnt i innledningen har mange russere fått økte sosiale utfordringer etter overgangen til et liberalt og markedsbasert system, da man ikke har lyktes i å gi folk flest grunnleggende økonomiske premisser for å kunne sørge for seg selv (Maltseva, 2016, s. 238). I dag står mange utenfor arbeidslivet eller har dårlig betalte og tidskrevende jobber, og utfordringer relatert til boligforhold er utbredt (Dementeva, 2016, s. 290). Ofte er det snakk om alenemødre, som i tillegg til å være alene med barneomsorgen, i ekstra stor grad sliter med de ovennevnte utfordringene relatert til jobb og bolig (Dementeva, 2016, s. 287; Johnson et al., 2014, s. 174).

Ifølge offentlig statistikk levde 13,2 prosent av den russiske befolkningen i 2017 på mindre enn minstelønn, ${ }^{2}$ og blant barn som levde i slike familier var denne andelen 25,9 prosent. Samme år bodde 29 prosent av russiske barn i familier hvor omsorgsansvaret lå på alenemødre (Rosstat, 1999-2019; 2003-2017). Foreldres inntekt og sosiale status kan påvirke barnas psykiske helse direkte i form av psykiske lidelser, men det kan også få konsekvenser for barna indirekte. Marginalisering kan føre til en følelse av skam og tap av verdighet hos foreldrene. Denne sammenhengen kan være spesielt utbredt i land der sosiale forskjeller er store og velferdssystemet er svakt. Marginaliseringen kan i slike tilfeller påvirke hvordan foreldrene ser på sin egen betydning for barn og deres utvikling, og dermed også hvilken omsorg de faktisk klarer å tilby (Andenæs, 2004, s. 26; Kinge et al., 2021, s. 11; Ward et al., 2012). En elementær del av å hjelpe foreldre er altså å sikre at de kan forsørge barna, for så å jobbe videre med andre utfordringer som ofte er tett knyttet til og springer ut fra marginaliseringen. Derfor er det sentralt å se på hvilke muligheter sårbare familier i Russland har til å få hjelp til å forsørge sine barn.

${ }^{2}$ I 2017 var minstelønnen på 10088 rubler, hvorav gjennomsnittslønnen var på 39167 rubler (Rosstat, 1999-2019). 
Mine informanter tegner et bilde av at statlige tiltak med økonomisk støtte rettet mot de mest sårbare familier enn så lenge er feilslått. Lov nr. $42 \mathrm{om}$ sosial støtte til den russiske befolking introduserte et sett med tiltak for å kartlegge og motvirke faktorer som forverrer russeres levekår (Zakon 442, 2013). Denne loven la også til rette for opprettelsen av et offentlig register av ulike tilgjengelige tjenesteytere, både statlige, private og NGO-er. På den ene siden søkte loven å dra nytte av de ressurser NGO-er har til å kompensere for manglene ved den statlige velferden. På den andre siden ville registeret gjøre det enklere for folk å finne frem til riktige tiltak (Cook, 2015, s. 2342, s. 2344; Prikaz Mintruda, 2014). Brukerne av systemet skulle kunne lete seg frem til de tiltak de har behov for, fra de sosiale aktørene som de mener passer dem best. En av informantene kaller dette en slags «tjenestebutikk», ${ }^{3}$ hvor klienten selv må oppsøke og "handle» de riktige tjenestene (Gjertsen, 2007, s. 59; Intervju 6). Det russiske systemet er med andre ord basert på det mine informanter kaller et "deklarativt prinsipp", hvor enhver person aktivt må erkjenne og ytre sitt behov for støtte. I tråd med Tsjernovas (2013, s. 76, s. 80) beskrivelse av det moderne velferdssystemet som minimalistisk og liberalt, underbygger dette at det russiske velferdssystemet er basert på stor negativ frihet.

Registeret for tilgjengelige tjenesteytere beskrives dog av mine informanter som lite hensiktsmessig idet det er lite oppdatert og ineffektivt. Det er komplisert for organisasjoner å registrere seg, og de må ofte innordne seg og tilby tjenester som staten anser som hensiktsmessige for å få støtte, noe som fører til at mange tjenesteytere mister sin autonomi, og lar være å registrere seg og søke om finansiering. Organisasjonene får dermed et mer begrenset tilbud og mindre synlighet overfor brukerne (Cook, 2015, s. 2347; Intervju 9). Denne tendensen er i seg selv ikke unik for Russland; også Norge har stått ovenfor lignende utfordringer (Gjertsen, 2007, s. 59). Men i Russland, et samfunn med store sosiale forskjeller og hvor rammeverket for velferdssystemet er vanskelig å manøvrere innenfor, fremstår dette som ekstra uheldig. Det er tross alt ofte slik at de som er svakest stilt og har størst behov for støtte, også har vanskeligst for å identifisere sitt konkrete behov og oppsøke den aktuelle støtten (Gjertsen, 2007, s. 59).

Videre, dersom en person først har funnet frem til de tjenestene hen har behov for, må vedkommende gå gjennom en omfattende byråkratisk prosess for å bevise sin nød og at hen kvalifiserer for de foreslåtte tiltakene. Dette kan oppleves både som svært vanskelig, men også nedverdigende og ytterligere marginaliserende (Alsjanskaja, 2019a). Mange kvier seg derfor for i det hele tatt å starte prosessen med å søke hjelp, og enkelte er i tillegg redde for at den påviste sosiale nøden vil føre til at barnevernet automatisk kobles inn. Grunnet dette kompliserte systemet er det tilsynelatende få av de som virkelig trenger støtte, som har tilstrekkelig ressurser til å gjøre krav på de tjenester de har behov for. Dermed ser vi at tiltak som kunne

\footnotetext{
${ }^{3}$ Denne og påfølgende oversettelser fra russisk til norsk er gjort av undertegnede.
} 
ha forebygget sosiale problemer som i stor grad fører til sosial foreldreløshet, er av variabel og mangelfull karakter. Mange sårbare familier forblir dermed på sidelinjen av systemet under det kritiske stadiet når deres sosiale situasjon fremdeles hadde vært mulig å snu. Konsekvensen blir ofte at situasjonen tilspisser seg i en slik grad at barnevernet kobles inn.

Den russiske familieloven fra 1995 danner grunnlaget for hvordan barnevernet kan intervenere i en familie (Schmidt \& Schurko, 2014, s. 451; Semejnyj kodeks, 1995). Måten barnevernet blir involvert i en familie kan arte seg ulikt. Overordnet kan man snakke om tre scenarioer: akutt inngripen, inngripen etter lengre tids undersøkelser og frivillig omsorgsoverføring på midlertidig basis.

Første alternativ skjer i de tilfeller der barnevernet oppdager akutte forhold som tilsier at barnet må tas ut av familien med umiddelbar virkning. Dette kan være at barna observeres uten tilsyn eller andre forhold som setter barna i umiddelbar fare (Semejnyj kodeks, 1995, \ 77). I denne forbindelse må det nevnes at flere informanter hevdet at retningslinjene for hva som kvalifiseres som umiddelbar fare er vage, noe som levner en slik vurdering til hver barnevernsansatts eget skjønn. Denne observasjonen bekreftes også av Sidorova og Rockhill (2016, s. 50). En personlig vurdering kan innebære at situasjonen helhetlig vurderes som mindre akutt enn ett enkelt tilfelle kan tilsi, og man ser etter andre løsninger. På den andre siden kan en personlig evaluering også innebære at en situasjon vurderes som mer alvorlig enn den i virkeligheten er, spesielt dersom stigmatisering finner sted. Videre innebærer akutt inngripen mye ekstra arbeid for barnevernsarbeiderne, og det stilles strenge krav til en rekke dokumenter som må fremstilles for retten innen en stram tidsramme. Derfor forsøker mange å unngå denne typen inngripen, og man løser det akutte tilfellet ved å koble inn politiet for midlertidig å hente barnet, og så benytter man seg av andre alternativer for videre arbeid med familien (Birjukova et al., 2013, s. 62; Intervju 7). Et slikt alternativ er for eksempel å foreta lengre tids undersøkelser av familien, en utbredt metode som brukes til å kartlegge en familiesituasjon etter mottakelse av mindre akutte bekymringsmeldinger.

Flere informanter forteller om tilfeller hvor foreldre frasier seg omsorgen på en midlertidig basis. Dette kan skje ved at foreldrene selv oppsøker hjelp fordi de trenger noen til å ta seg av barna over en periode grunnet sykdom, søken etter jobb eller fast bolig, eller ved at barnevernet har som intensjon å jobbe forebyggende med foreldrene for å hindre fast omsorgsovertakelse. Dette alternativet reflekterer en trend hvor man ser en nedgang $i$ antall faste omsorgsovertakelser og en tilsvarende økning i midlertidige omsorgsovertakelser. Fra 2002 til 2018 økte andelen midlertidige overtakelser, regnet ut fra det totale antallet omsorgsovertakelser, fra 5,7 prosent til 22,2 prosent (Birjukova \& Marakentseva, 2020; Birjukova \& Sinjavskaja, 2017, s. 372). Denne utviklingen kunne ha vitnet om at det russiske barnevernet beveget seg mot en serviceorientert strategi, dersom det fantes reelle tiltak som var ment å hjelpe foreldrene (Krutzinna \& Skivenes, 2020, s. 51). Men, som en informant påpeker, blir ikke slike tiltak implementert i særlig stor grad: «Hvem vil jobbe med 
foreldrene når barnet ikke lenger er i familien? [...] Det viktigste er allerede oppnådd, nemlig å få barnet fjernet» (Intervju 3). Mangelen på forebyggende tiltak fører dermed til at årsakene til den midlertidige omsorgsovertakelsen aldri blir overkommet, og midlertidigheten blir i praksis permanent (Birjukova \& Marakentseva, 2020; Birjukova \& Sinjavskaja, 2017, s. 379; Jäppinen, 2020; Sidorova \& Rockhill, 2016).

I tillegg har andelen barn som blir returnert til sine biologiske familier, regnet ut fra den totale andelen barn som blir plassert i familieomsorg, ligget uendret på omtrent 20 prosent siden 2014, noe som bekrefter mangelen på arbeid med barnas biologiske familie (Birjukova \& Marakentseva, 2020). Det kan altså synes som at den viktigste oppgaven for barnevernet fremdeles i praksis er å få barnet $u t$ av situasjonen, altså risikohåndtering og beskyttelse av barnet, men ikke å giøre noe med situasjonen i seg selv og å tenke familie- og serviceorientert.

Vi ser dermed at det russiske velferdssystemet i sin deklarative og lite tilgjengelige form skaper et stort rom for negativ frihet der mange sårbare familier lever sine liv uten hjelp fra staten, og grunnet sosiale utfordringer ikke klarer å realisere sin positive frihet. Når staten intervenerer, er det i form av et risikoorientert barnevern som ikke ser helhetlig på familiens situasjon. Spørsmålet blir da om denne situasjonen har sitt utgangspunkt $i$ en uoverensstemmelse mellom sårbare familiers sosiale forutsetninger på den ene siden, og samfunnets og barnevernets forventninger på den andre.

\section{Sosialt stigma og dets rolle i det forebyggende arbeidet med sårbare familier}

Innenfor ethvert samfunn eksisterer verdier og forventinger som gjenspeiler samfunnets komplekse situasjon, som igjen vil være betinget av både historien så vel som nåværende politiske og sosiale struktur (Hove, 2001, s. 47). Mange faktorer vil dermed påvirke hvilke forventninger russere har til hverandre i dag. Man kan for eksempel trekke frem at sovjettidens likhetsidealer kan ha ført til overdreven stigmatisering av alt som er annerledes (Fujimura, 2002, s. 44-45). Holdninger som bunner i det sovjetiske idealet om en kjernefamilie med en mor og en far, ansvarsfulle, hardtarbeidende foreldre med høy moral, er også av betydning. Slike holdninger har gitt opphav til normative forventninger om at alle må gjøre nytte for seg i samfunnet (Höjdestrand, 2009, s. 2, s. 6; Rockhill, 2010, s. 139-140). Til sist har tradisjonelle familieverdier, som understreker viktigheten av blant annet tokjønnet foreldreskap og kjønnsrollefordeling der mor anses som hovedansvarlig for barneomsorg, blitt stadig mer fremtredende i den senere tid (Höjdestrand, 2016, s. 831; Sidorova \& Rockhill, 2016, s. 45). Dette vitner om at det både i en sovjetisk så vel som i en moderne russisk tankegang finnes tydelige sosiale forventninger til hvordan en familie og dens medlemmer bør være og leve.

Dersom man ikke tilfredsstiller disse forventningene, er sjansen stor for å bli plassert i kategorien neblagopolutsjnyj. Dette er et diffust definert begrep relatert 
til sosial og/eller økonomisk marginalisering, og som i kraft av å være nettopp diffust kan danne grunnlaget for stigmatisering (Jarskaja-Smirnova et al., 2014). Neblagopolutsjnyj kan innebære at man er materielt fattig, aleneforsørger, alkoholiker eller kun ansett som amoralsk (Sidorova \& Rockhill, 2016, s. 40-41). Jeg velger videre å oversette neblagopolutsjnyj med mislykket. Spørsmålet er så om besittelsen av én av de ovennevnte faktorene fører til at man får seg påskrevet også de øvrige. Selv om flere av mine informanter anerkjente at det er stor variasjon angående grad og utbredelse, ga flere av dem klart uttrykk for at stigmatisering på grunnlag av mislykkethet er til stede blant de som arbeider i barnevernet og sosiale tjenester. Det stilles for eksempel ofte spørsmål som «hvorfor har de fått barn?» om fattige foreldre, noe som insinuerer at det anses som amoralsk å få barn dersom man er mindre velstående enn gjennomsnittet. Slike holdninger fremstår som tvetydige gitt statens fokus på å snu en nedadgående demografisk trend gjennom å støtte familier økonomisk til å få flere barn (Höjdestrand, 2016, s. 830).

Uttrykket «slike mødre» er vanlig å høre rundt om i samfunnet så vel som innad i barnevernet, og det kan kobles til kategorien mislykket. Som et eksempel uttalte en representant for Barneombudet (Intervju 8) at "slike mødre» ofte mangler adekvat morsinstinkt, og at det synes som at morsinstinktet er i ferd med å svekkes på generell basis i det russiske samfunnet i dag. Rockhill (2010) hevder at barnevernsansatte ser på morsinstinkt, altså en biologisk kategori, nærmest som et synonym til det å være en egnet forelder, noe som involverer en kompleks sammensetning av langt flere kategorier enn kun biologi. Det at sårbare foreldre kalles for «slike mødre», kan dermed peke mot tilstedeværelsen av fordommer som tilsier at økonomisk og sosialt utsatte mødre, i det de blir regnet som ikke-besittende av morsinstinkt, a priori er dårlig kvalifiserte som foreldre. Dette bygger opp under at besittelsen av én egenskap som kan relateres til kategorien mislykket medfører at man blir påskrevet resten av egenskapene. Den biologiske forbindelsen mellom foreldre og barn kan dermed sies å bli brukt på en tvetydig måte av statlige ansatte. Som blant annet Rockhill (2010, s. 316) viser, ser barnevernet i stor grad bort fra det biologiske båndet mellom foreldre og barn i sin reaktive måte å hjelpe barn i sårbare familier på når de hyppig fjerner barnet fra foreldene. Samtidig blir biologi altså tillagt vekt ved at kategorien «dårlige omsorgsgener» ofte brukes til å forklare at visse foreldres dårlige omsorgsevne er arvelig. Denne måten å forholde seg til den biologiske forbindelsen mellom barn og foreldre på gir barnevernet et spillerom til å fraskrive seg ansvaret for å endre situasjonen.

For eksempel er en slik tvetydighet gjeldende i møtet mellom barnevernet og tidligere barnehjemsbarn. Som nevnt i innledningen møter denne gruppen ofte store utfordringer i sine voksenliv. Mine informanter hevder at i stedet for å se dette som en konsekvens av den institusjonelle barndommen som staten har gitt barnehjemsbarna, forhåndsdømmer både samfunnet og barnevernet dem basert på deres foreldreløshet og deres foreldres angivelige nedarvete uegnethet som omsorgspersoner. Når de så møter utfordringer i å skulle ta vare på egne barn, får de sjelden 
hensiktsmessig oppfølging, men blir, ifølge Elena Alsjanskaja, lederen for veldedighetsfondet Frivillige hjelper foreldreløse barn, møtt av «trusler, fordommer og krav. Og videre trekker barnevernet følgende konklusjon: denne familien har ikke gjort sitt ytterste for sitt barns interesser fordi den er 'slik'” (Ivanusjkin, 2019). En av mine informanter fortalte i denne forbindelsen hvordan en mor, som selv hadde vokst opp på et barnehjem, hadde blitt truet av barnevernet med at de basert på hennes historikk ville være ekstra oppmerksomme på tegn til vold mot barnet hennes, som for eksempel blåmerker. Full av frykt og uten en fullstendig forståelse av situasjonen satte denne moren en hjelm på barnet sitt $\mathrm{i}$ et forøk på å unngå at barnet skulle slå seg under lek. At denne moren hadde helt andre behov for oppfølging rundt omsorgen for sitt barn, ble ikke adressert (Intervju 10). Konsekvensene av at staten en gang frarøvet disse foreldrene en barndom som ville ha gitt dem de nødvendige premissene for å kunne bli gode foreldre selv, blir tilsynelatende avskrevet som en nedarvet last og et individuelt ansvar (Krutzinna \& Skivenes, 2020, s. 52).

Manglende omsorgsevne kan visstnok sies å gå i arv i den forstand at omsorgssvikt i en generasjon ofte fører til det samme i neste, gitt at slike ferdigheter, eller mangelen på dem, føres videre i et relasjonelt perspektiv (Ward et al., 2012). I denne sammenhengen ser likevel stigmaet overfor sårbare foreldre ut til å være knyttet til synet på at gode foreldreegenskaper betinges av arvelighet i ren biologisk forstand (Fujimura, 2002, s. 45). I lys av prinsippet om at mennesket har potensiale for sirkulær utvikling i samsvar med sine omgivelser, som ligger til grunn for den familieorienterte strategi, vil det å evaluere foreldrenes kapasitet til å endre seg være en viktig del av barnevernets arbeid (Gjertsen, 2007, s. 105). Med utgangspunkt i dette, kan nettopp det biologiske fokuset på «dårlige omsorgsgener» være med på å forklare hvorfor sosialt arbeid med foreldrene fremdeles blir viet lite oppmerksomhet $\mathrm{i}$ Russland, tross paradigmeskiftet. Man ser en holdning blant barnevernsansatte som sier at at enten er du født med det som kreves for å være en god forelder, eller så er du det ikke, og det er lite sosialarbeidere kan gjøre for å påvirke dette (Jäppinen, 2020; Krutzinna \& Skivenes, 2020, s. 52).

En annen faktor som springer ut av utsagnet "slike mødre», er kjønnsperspektivet. Det er nettopp mødre som ofte står i fokus når det gjelder evalueringen av foreldreegnethet (Krutzinna \& Skivenes, 2020, s. 52). Som nevnt ovenfor, viser statistikken at det er en stor andel alenemødre innenfor kategorien sosialt og økonomisk sårbare familier i Russland. Alenemødre befinner seg ofte i en ond sirkel av sårbarhet, der det å ha aleneansvaret for barn kan giøre det spesielt vanskelig å ha en fast jobb og fast og tilfredsstillende bolig. Ordnede jobb- og boforhold er premisser som det blir lagt stor vekt på i det russiske samfunnet i spørsmål om en person giør nytte for seg og således kan regnes som en egnet omsorgsperson (Sidorova \& Rockhill, 2016, s. 50). Dersom en alenemor har en jobb å gå til, eller bruker tid på å søke hjelp til å løse sine utfordringer, blir hun av samfunnet ofte beskyldt for å overlate barna til seg selv, eller gi ansvaret til andre omsorgspersoner, og hun tilfredsstiller dermed ikke forventningen om at en god mor skal passe sine egne barn hjemme (Sidorova 
\& Rockhill, 2016, s. 48-51). Følgelig faller alenemødre utenfor en eller annen norm uansett hva de gjør, og står i fare for å møte stigmatisering fra ulike hold. De lever ikke i en tradisjonell kjernefamilie, og de havner i en uløselig konflikt mellom forventningen om at moren skal være hjemme og ta seg av barnet på den ene siden, og forventningen om å gjøre nytte for seg i samfunnet på den andre.

Mine informanter tegner dermed et bilde av at stigmatisering av marginaliserte og sosialt sårbare familier ofte forekommer blant barnevernsansatte som i kraft av statlige reformer er ment å ha et økt fokus på forebyggende arbeid. Satt inn i system, kan denne stigmatiseringen ikke bare føre til feilaktig og reaktiv oppfølging av familier som trenger økonomisk og sosial hjelp, men det kan også føre til at oppmerksomheten trekkes bort fra velstående familier, hvor vold og annen omsorgssvikt kan være vel så utbredt som i mindre velstående familier (Intervju 5; Intervju 6). Det kan altså synes som at fokuset på familien innenfor det russiske barnevernet er en tvetydig strategi og praktiseres mer snevert enn intendert, for ikke å nevne skjevt mellom ulike lag i befolkningen basert på deres sosiale status.

Hvordan barnevernsansattes stigmatisering får fremtre og betinge i hvilken grad de velger å implementere forebyggende arbeid, avhenger av flere faktorer. Samtlige av mine informanter trakk frem den menneskelige faktors sterke tilstedeværelse, altså hvordan personlige holdninger og vurderinger påvirker arbeidet ved statlige etater, i kontrast til det å skulle jobbe etter objektive retningslinjer fastsatt på et faglig og etisk grunnlag. Som Alsjanskaja (2019b) hevder, kan det synes som at det i stor grad er "mannen i gata» som jobber i barnevernet, og ikke objektive yrkesutøvere. ${ }^{4}$ Andre informanter kalte det samme fenomenet vurdering ved "øyemål» (na glazok), i den betydning at barnevernsansatte baserer slutninger om sårbare foreldre er egnede omsorgspersoner for sine barn på subjektive og gjerne visuelle vurderinger. Dette kan blant annet være knyttet til manglende eller mangelfull spesialisert utdannelse rettet både mot barnevern og sosial bistand i Russland (Höjdestrand, 2016, s. 837). Til tross for at det planlegges for mer spesialiserte utdanninger, er russiske utdanninger knyttet til den sosiale sfære $i$ all hovedsak teoretiske og for generelle, mens de mangler praktisk forankring i feltet og konkret kunnskap innenfor fagområder som for eksempel barnepsykologi, traumebehandling og barns psykiske helse (Birjukova et al., 2013, s. 79; Intervju 9; Jarskaja-Smirnova et al., 2014, s. 223-224, s. 230; Johnson et al. 2014, s. 175).

Videre hevder en informant at barnevernsansatte med utdanning, om enn ikke $i$ en spesialisert forstand, enten nylig har fullført utdanningen, og mangler erfaring, eller nærmer seg pensjonsalder, og kan tenkes å ha manglende motivasjon for å omstille seg i henhold til nye anbefalte retningslinjer (Intervju 5). Informantene skisserer et bilde av hvordan for eksempel eldre kvinner i barnevernet baserer sine vurderinger av familiene på egne erfaringer som mødre og et ideal som stammer fra et

${ }^{4}$ Facebook-uttalelse, forfatteren har gitt tillatelse til henvisning. 
sosialistisk moralsk kompass og ikke dagens, noe som også stemmer med Rockhill (2010, s. 140) sine observasjoner. Dette moralske kompasset kan på den ene siden være betinget av det ovennevnte spørsmålet om å giøre nytte for seg i samfunnet, som var en klar forventning innenfor den sosiale kontrakten mellom den sovjetiske staten og befolkningen (Höjdestrand, 2009, s. 2, s. 6; Maltseva, 2016, s. 231). Det moralske kompasset tilsier dermed at dersom man for eksempel er arbeidsledig og ikke kan gjøre nytte for seg i samfunnet, så kan man heller ikke forvente sosial støtte. På den andre siden kan slike holdninger være relatert til at den sosiale skjevheten som faktisk fantes under Sovjetunionen i stor grad ble skjult. Dette kan ha ført til en offentlig uvillighet til å anerkjenne at enkelte grupper mennesker har sosiale utfordringer som er strukturelt betingede og som er et offentlig ansvar. Ifølge Höjdestrand (2009, s. 40) er ikke fordommene nødvendigvis ondsinnede, men kan være et resultat av mangel på et alternativt narrativ.

Barnevernsansatte stigmatiserer også familier på bakgrunn av vurderinger av materielle levekår (Sidorova \& Rockhill, 2016, s. 41). Flere informanter fortalte at det materielle fokuset de senere år har minket i tråd med at kriteriene for omsorgsovertakelse er blitt noe tydeligere. Likevel hevdet de at vurderinger basert på visuelle førsteinntrykk av familiene fremdeles er fremtredende. Som Sidorova og Rockhill (2016, s. 51) også fremhever, kan synet av en ølflaske i en families søppelkasse, eller at en kvinne ser eldre ut enn det alderen tilsier, føre til generaliseringer om at vedkommende er en alkoholiker. Det kan med andre ord synes som at sosialarbeidere trekker på et narrativ om sosiale vansker som de tolker foreldrenes tilsynelatende karakterdefekter ut fra. Stigmatiseringen basert på førsteinntrykk får dermed en definerende effekt på hvordan familiene blir fulgt opp videre av barnevernet (Goffman, 2011, s. 12; Hove, 2001, s. 12-13, s. 21; Spicker, 1984, s. 46). En søken etter en helhetlig forståelse av en families svakheter og styrker, samt potensial for å overkomme deres utfordringer, forekommer derimot mer sjeldent (Alsjanskaja, 2019a; Intervju 9).

En siste faktor som påvirker stigmatiseringen, er systemets rigiditet. Det er, ifølge mine informanter, indikasjoner på at tverrfaglig og tverretatlig samarbeid på lokalt nivå, der arbeidet med familiene i praksis foregår, er begrenset (Intervju 2; Intervju 9). Som en informant forklarte, fører mangel på samarbeid blant annet til at ansvaret for ulike områder forblir spredt over mange etater (Intervju 3). Dette kan føre til mindre grad av kunnskapsutveksling og gjensidig balansering av argumenter blant de ansatte, og som følge av det kan stigmatisering utfolde seg blant de ansatte (Gjertsen, 2007, s. 98).

Det finnes altså tilsynelatende et gap mellom offisielle reformer og barnevernets forventninger overfor sårbare familier på den ene siden, og den praktiske virkeligheten med høye fattigdomstall, systemisk rigiditet, mangelfull utdannelse blant sosialarbeidere, stor plass til enkeltmenneskers bruk av skjønn, samt forskjellbehandling basert på brukernes sosiale status på den andre. Forventningene baserer seg både på et fokus på tradisjonelle familieverdier og et syn på at sosiale vansker er biologisk 
forankret, og dersom man faller utenfor, så skyldes det karaktersvakhet. Når sosialarbeidere anser sosial sårbarhet som biologisk betinget legges det til rette for at stigma kan spille en definerende rolle i det at sosial og økonomisk sårbarhet anses som et individuelt, i motsetning til et kollektivt, ansvar. Dette fører til at flere familier ikke anses som verdige eller hensiktsmessige mottakere av forebyggende familieorienterte tiltak. Det synes dermed ironisk at de tradisjonelle familieverdier, som retorisk sett var ment å danne grunnlaget for barnevernsreformen og paradigmeskiftet, tilsynelatende er med på å hindre at endringene faktisk blir gjennomført.

\section{Konklusjon}

John Donne skrev en gang at "[n]o man is an island» (1624), og mennesker har alltid vært avhengige av hverandre, i større eller mindre grad. Også det å oppdra et barn har i mange kulturer historisk sett vært et kollektivt anliggende, i nærvær av en storfamilie, naboer eller andre som utfyller foreldrene. I dag har dog staten mange steder erstattet dette kollektivet. Likevel er grunnkonseptet det samme, nemlig at man trenger andre for å utføre en så stor oppgave som å oppdra et barn. Familier trenger for eksempel muligheten til å få et rimelig barnehagetilbud slik at foreldrene kan jobbe, muligheten til å ta opp boliglån eller muligheten til å få gode tilbud om terapi og veiledning i møte med livets store og små utfordringer. Behovet for et kollektiv som strekker seg ut over kun et foreldrepar vil, mer eller mindre direkte, allid være til stede rundt et barn. Steder hvor en individualisering av samfunnet har forankret seg parallelt med at staten ikke kompenserer for det tapte kollektivet gjennom tilfredsstillende sosial velferd, kan oppleve konsekvenser som kan ramme deres barn. Samtidig kan stigmatisering av sårbare familier føre til at de faller utenfor samfunnets kollektiv, og minke deres sjanser for å kunne ivareta sine barn på en tilfredsstillende måte.

I denne artikkelen har jeg vist at det i dagens Russland kan observeres nettopp en slik utvikling. Endringer i det sosiale velferdssystemet siden Sovjetunionens fall har gjort stadig flere familier mer sosialt sårbare, samtidig som forventningene fra barnevernet tar utgangspunkt $i$ at familiene fremdeles bør møte en predefinert sosial standard. Siden Sovjetunionens oppløsning har Russland gjennomgått en turbulent transisjon fra et sosialistisk samfunn, hvor innbyggernes grunnleggende behov i større grad ble ivaretatt av det statlige velferdssystemet, og hvor man med en viss grad av legitimitet kunne forvente at hver og en skulle leve opp til samfunnets forventninger om et velfungerende liv. Det sosialistiske samfunnet har så blitt erstattet av et stadig mer individualistisk system, hvor avstanden mellom stat og innbygger har vokst, og grunnleggende behov ikke lenger garanteres i like stor grad. Samtidig synes det fremdeles legitimt å forvente at samtlige innbyggere skal kunne leve velfungerende liv. Mine informanter forteller at dersom enkelte familier faller utenfor normalen, følger den moralske fordømmelsen fra menneskene rundt så vel som fra statlige representanter tett etter. 
Artikkelen søker ikke å sette sovjetsystemet normativt opp mot nåtidens system, og heller ikke å ubetinget kategorisere økonomisk og sosialt sårbare familier som ofre og se bort fra at det finnes mange komplekse grunner til at barn opplever omsorgssvikt. Likevel har jeg vist at det er mangel på samsvar mellom de forutsetninger som gis, spesielt til samfunnets minst ressurssterke, og de forventninger som stilles. I stedet for å få hensiktsmessig støtte, møtes mange sårbare familier med reaktive tiltak som minner mer om en barnebeskyttelses- enn en familieorientert strategi. Ved hjelp av Berlins teoretiske begreper kan man altså antyde at den negative friheten er stor i Russland, og at forebyggende inngripen kunne ha gitt positive resultater. Likevel, gitt den begrensede positive friheten de mest sårbare borgerne besitter innenfor et mangelfullt velferdstilbud og et samfunn som i stor grad er preget av sosialt stigma overfor slike grupper, er ikke sårbare familier i stand til å realisere sin positive frihet og leve slik både de selv og samfunnet forventer av dem.

Stigma kan skapes gjennom antakelser om sammenhengen mellom visse egenskaper og visse kategorier mennesker. Det russiske samfunnet både skaper og håndterer sosial foreldreløshet giennom et prisme som betinges av at enkelte familier stigmatiseres som mislykket. På den ene siden danner begrepet grunnlag for å ta barn fra foreldre som er sosialt avvikende gitt at foreldrene ikke anses å være i stand til å endre sin situasjon. På den andre siden legitimerer det at man lukker øynene for de systemiske problemene idet man plasserer skylden utelukkende på individnivå. Til sist legitimerer det, i tråd med koblingen mellom fattigdom og avvik, også et manglende fokus på omsorgssvikt i mer velstående familier der vold og deprivasjon kan være vel så aktuelt. Dermed kan begrepet sosial foreldreløshet kalles en eufemisme. Tradisjonelt sett brukes begrepet til å beskrive hvordan barn blir forlatt og sviktet av sine avvikende foreldre, mens det i lys av det ovennevnte burde rettes mer oppmerksomhet mot at det kanskje var staten og samfunnet som sviktet foreldrene i første omgang. ${ }^{5}$

\section{Referanser}

Alsjanskaja, J. (2019a, 19. mars). Blagotvoritelnost s Tatjanoj Konstantinovnoj. Mediametrics [radiointervju med Jelena Alsjanskaja]. Hentet 19. mars 2019 fra http://radio.mediametrics.ru/Blagotvoritelnost_s\%20 Tatiana\%20onstantinovna/61666/

Alsjanskaja, J. (2019b). Innlegg på Facebook. Hentet 19. mars 2019 fra https://www.facebook.com/Jelena Alshanskaya

Andenæs, A. (2004). Hvorfor ser vi ikke fattigdommen? Fra en undersøkelse om barn som blir plassert utenfor hjemmet. Nordisk sosialt arbeid, 24(1), 19-33. https://doi.org/10.18261/ISSN1504-3037-2004-01-03

Berlin, I. (1958). Two concepts of liberty. Oxford University Press.

Bindman, E., Bogdanova, E. \& Kulmala, M. (2018). NGOs and the policy-making process in Russia: The case of child welfare reform. Governance, 32(2), 207-222. https://doi.org/10.1111/gove.12366

Birjukova, S., Sinjavskaja, O. \& Varlamova, M. (2013). Sirotstvo v Rossii: Osnovnyje tendentsii i prioritety gosudarstvennoj politiki. SPERO. Sotsialnaja politika: ekspertiza, rekomendatsii, obzory, 18, 57-80. https:// publications.hse.ru/articles/94304210

\footnotetext{
${ }^{5}$ Inspirert av Rockhills (2010) påstand om at sosial foreldreløshet er en eufemisme, men undertegnedes bruk av begrepet er tilpasset.
} 


\section{4 | TRINE SKOGSET OFITSEROVA}

Birjukova, S. \& Sinjavskaja, O. (2017). Children out of parental care in Russia: What we can learn from the statistics. Zjurnal issledovanij sotsialnoj politiki, 15(3), 367-382. https://cyberleninka.ru/article/n/childrenout-of-parental-care-in-russia-what-we-can-learn-from-the-statistics

Birjukova, S. \& Makarentseva, A. (2020). Statistics on the deinstitutionalization of child welfare in Russia. I M. Kulmala, M., Jäppinen, A. Tarasenko \& A. Pivovarova (red.), Reforming child welfare in the post-Soviet space: Institutional change in Russia [Perlego] (Kap. 1). Routledge.

Cook, L. (2011). Postcommunist welfare states: Reform politics in Russia and Eastern Europe. Cornell University Press.

Cook, L. (2015). New winds of social policy in the East. Voluntas, 26(6), 2330-2350. https://doi.org/10.1007/ s11266-015-9642-7

Cook, L. \& Dimitrov, M. (2017). The social contract revisited: Evidence from communist and state capitalist economies. Europe-Asia Studies, 69(1), 8-26. https://doi.org/10.1080/09668136.2016.1267714

Dahl, T. \& Schmidt, N. (2020, 10. mars). To nye fellelser mot Norge i EMD. Advokatbladet. https://www. advokatbladet.no/barnevern-emd/to-ny-fellelser-mot-norge-i-emd/148496

Dementeva, I. F. (1992). Sotsialnaja adaptatsija detej-sirot: problemy i perspektivy v uslovijakh rynka. Sotsiologitsjeskije issledovanija,10,62-70.http://ecsocman.hse.ru/data/917/208/1217/010.DEMENTIEVA. pdf

Dementeva, I. F. (2016). Faktory riska razvitija detstva v sovremennoj Rossii. Vestnik RUDN, Sotsiologija, 16, 285-294. https://cyberleninka.ru/article/n/faktory-riska-razvitiya-detstva-v-sovremennoy-rossii

Donne, J. (1624). Devotions upon emergent occasions and several steps in my sickness: Digested into I. Meditations upon our humane condition, 2. Expostulations, and debatements with God, 3. Prayers, upon the several occasions, to Him. Skrevet for Thomas Iones.

Firsov, M. (2005). Help and support to orphans in Russia: The historical path. I J. Holm-Hansen (red.), Placement of orphans. Russian and Nordic experiences (s. 55-61, NIBR Working Paper:137). NIBR.

FNs barne konvensjon. (1989). FNs konvensjon om barns rettigheter. FN. Hentet 03. juli 2020 fra https:// www.ohchr.org/EN/ProfessionalInterest/Pages/CRC.aspx

Fog, J. (1996). Begrundelsernes koreografi. Om kvalitativ ikke-statistisk repræsentativitet. I H. Holter \& R. Kalleberg (red.), Kvalitative metoder $i$ samfunnsforskning (s. 194-219). Universitetsforlaget.

Fujimura, C. (2002). Adult stigmatization and the hidden power of homeless children in Russia. Demokratizatsija, 10(1), 37-47.

Fujimura, C., Stoecker, S. \& Sudakova,T. (2005). Russia's abandoned children: An intimate understanding. Prager Publishers.

Gilbert, N., Parton, N. \& Skivenes, M. (2011). Introduction: Changing patterns of response and emerging orientations. I N. Gilbert, N. Parton \& M. Skivenes (red.), Child protection systems: International trends and orientations (s. 3-13). Oxford University Press.

Goffman, E. (2011). Stigma. Den avvikandes roll och identitet (3. utg.) (R. Matz, Overs.). Norstedt.

Holm-Hansen, J., Kristofersen, L. B. \& Myrvold, T. M. (red). (2003). Orphans in Russia. Policies for family like alternatives (NIBR-rapport 2003:1). NIBR.

Hove, O. (2001). Stigma. Teoretiske tilncerminger til stigma og til forholdet mellom stigma og sosiale ytelser-en kritisk drøfting (HiO-rapport 2001:2). Høgskolen i Oslo, Avdeling for økonomi-, kommunal og sosialfag.

Höjdestrand, T. (2009). Needed by nobody: Homelessness and humanness in post-socialist Russia. Cornell University Press.

Höjdestrand, T. (2016). Social welfare or moral warfare? Popular resistance against children's rights and juvenile justice in contemporary Russia. International fournal of Children's Rights, 24(4), 826-850.

Ivanusjkin, G. (2019, 22. april). Elena Alsjanskaja: osnovnaja problema v rabote s krovnymi roditeljamiisportsjennyj okuljar sotsialnykh sluzjb. Agenstvo sotsialnoj informatsij. https://www.asi.org.ru/2019/04/22/ elena-alshanskaya-sistema-raboty-s-krovnymi-semyami-eto-odin-bolshoj-sistemnyj-probel/

Jarskaja-Smirnova, E., Rasell, M., Brown, M. \& Strauss, H. (2014). Integrating practice into Russian social work education: Institutional logics and curriculum Regulation. International Social Work, 57(3), 222-234. https://doi.org/10.1177/0020872813519660

Johnson, D., Dovbnya, S., Morozova, T., Richards, M. \& Bogdanova, J. (2014). From institutional care to family support: Development of an effective early intervention network in the Nizhny Novgorod region, Russian Federation, to support family care for children at risk for institutionalization. Infant Mental Health fournal, 35(2), 172-184. https://doi.org/10.1002/imhj.21433

Jäppinen, M. (2020). No longer parents or parents in need of support? Views of child welfare experts on birth parents. I M. Kulmala, M. Jäppinen, A. Tarasenko \& A. Pivovarova (red.), Reforming child welfare in the post-Soviet space: Institutional change in Russia [Perlego] (Kap. 8). Routledge. 
Kalleberg, R., Malens, R. \& Engelstad, F. (2009). Samfunnsvitenskapenes oppgaver, arbeidsmåter og grunnlagsproblemer. Gyldendal Akademisk.

Kelly, C. (2007). Children's world: Growing up in Russia, 1890-1991. Yale University Press.

Kinge, J. M., Øverland, S., Flatø, M., Dieleman, J., Røgeberg, O., Magnus, M. C., Evensen, M., Tesli, M., Skrondal, A., Stoltenberg, C., Vollset, S. E., Håberg, S. \& Torvik, F. A. (2021). Parental income and mental disorders in children and adolescents: Prospective register-based study. International fournal of Epidemiology, 1-13. https://doi.org/10.1093/ije/dyab066

Kulmala, M., Rassel, M. \& Tsjernova, Z. (2017). Overhauling Russia's child welfare system: Institutional and ideational factors behind the paradigm shift. Zjurnal isseldovanij sotsial'noj politiki, 15(3), 353-366.

Kulmala, M., Jäppinen, M., Tarasenko, A. \& Pivovarova, A. (2020). In conclusion: The fragmented implementation of the new child welfare policy. I M. Kulmala, M. Jäppinen, A. Tarasenko \& A. Pivovarova (red.), Reforming child welfare in the post-Soviet space: Institutional change in Russia [Perlego] (Kap. 11). Routledge.

Maltseva, E. (2016). Framing a welfare reform: The social benefits reform in Russia and Kazakhstan. Canadian Slavonic Papers, 58(3), 229-256. https://doi.org/10.1080/00085006.2016.1202427

Mardakhajev, L.V. (2005). Sources of social orphanage at the turn of the millennium (end of 20th - beginning of 21 st centuries). I J. Holm-Hansen (red.), Placement of orphans. Russian and Nordic experiences (s. 52-54, NIBR Working Paper: 137). NIBR.

Midré, G. (1995). Bot, bedring eller nød? Om bedømming og behandling av sosial nød fra reformasjonen til velferdsstaten (2. utg). Universitetsforlaget.

Petrovskij, N., Cappa, C. \& Gross, P. (2017). Estimating the number of children in formal alternative care: Challenges and results. Child Abuse E Neglect, 70, 388-398. https://doi.org/10.1016/j.chiabu.2016.11.026

Prikaz Mintruda. (2014). Prikaz Mintruda Rossii No 940 ot 24 nojabrja 2014 g. Ministerstvo Truda. Hentet 16. april 2019 fra https://rosmintrud.ru/docs/mintrud/orders/485

Putin, V. (2013). Vladimir Putin vystupil na prokhodjasjtsjem v Moskve Siezde roditelej. Hentet 17. april 2019 fra http://www.kremlin.ru/events/president/news/17469

Roberts. S. (2013). Research in challenging environments: The case of Russia's 'managed democracy'. Qualitative Research, 13(3), 337-357. https://doi.org/10.1177/1468794112451039

Rockhill, E. K. (2010). Lost to the state: Family discontinuity, social orphanhood and residential care in the Russian far east. Berghahn Books.

Rockhill, E. K. \& Sidorova, E. (2016). Family on the edge. Neblagopoluchnaia family and the state in Yakutsk and Magadan, Russian Federation. Sibirica, 15(3), 31-63. https://doi.org/10.3167/sib.2016.150302

Rosstat. (1999-2019). Naselenije: demografija; uroven zjizni; zjilisjnyje uslovija; neravenstvo i bednost; semja, materinstvo, detstvo. Rynok truda, zanjatost, zarabotnaja plata: zarabotnaja plata. Federalnaja sluzjba gosudarstvennoj statistiki. https://rosstat.gov.ru/folder/12781

Rosstat. (2003-2017). Sotsialnoje polozjenije i uroven zjizni naselenija Rossii: 2003-2017. Federalnaja sluzjba gosudarstvennoj statistiki. Hentet 14. november 2018 fra http:/www.gks.ru/wps/wcm/connect/rosstat_ main/rosstat/ru/statistics/publications/catalo/doc_1138698314188

Schmidt, V. \& Schurko, T. (2014). Children's rights in post-Soviet countries: The case of Russia and Belarus. International Social Work, 57(5), 447-458.

Semejnyj kodeks. (1995). Semejnyj kodeks Rossijskoj Federatsii 29. Dekabrja 1995 No. 223. Hentet 10. juni 2020 fra http://docs.cntd.ru/document/9015517

Semja, G. (2009). Psikhologitsjeskaja zasjtsjisjtsjennost detej ostavsjikhsja bez popetsjenija roditelej, v uslovijakh institutsionalizatsii i zamesjtsjajusjtsjej smji. Psikhologitsjeskaja nauka i obrazovanije, 14(3), 24-32. https:// psyjournals.ru/psyedu/2009/n3/22765.shtml

Semja, G. \& Telitsina, A. (2016). Rol nekomertsjeskikh organizatsij i instituta dobrovoltsjestva v realizatsii Natsionalnoj strategii dejstvij v interezakh detej na 2012-2017 gody. Psikhologitsjeskaja nauka $i$ obrazovanije, 21(1), 168-183. https://rosstat.gov.ru/folder/210/document/13212

Semja, G, Zajtsev, G. \& Zajtseva, N. (2016). Formirovanije rossijskoj modeli preodolenija sotsialnogo sirotstva. Psikhologitsjaskaja nauka $i$ obrazovanie, 21(1), 67-82. https://psyjournals.ru/psyedu/2016/n1/semya_ zaytsev.shtml

Spicker, P. (1984/2011). Stigma and social welfare. Croom Helm.

Thagaard, T. (2003). Systematikk og innlevelse: En innføring i kvalitativ metode (2. utg.). Fagbokforlaget.

Tsjernova, Z. (2012). New pronatalism? Family policy in post-Soviet Russia. Region, 1(1), 75-92. 
Ukaz Prezidenta. (2012). Ukaz Prezidenta Rossijskoj Federatsii No 761. Hentet 05. april 2019 fra http:// kremlin.ru/acts/bank/25641

Ward, H., Borwn, R. \& Westlake, D. (2012). Safeguarding babies and very young children from abuse and neglect [Perlego]. Jessica Kingsley Publishers.

Westby, L. C. L. (2021). Sårbare barnefamiliers erfaringer fra møter med norsk barnevern: En narrativ studie [Doktoravhandling, Høgskolen i Innlandet]. https://hdl.handle.net/11250/2729575

Zakon 442. (2013). Federalnyj zakon ot 28.12.2013 g. No 442-Ф3 ob osnovakh sotsialnogo obsluzjivanija grazjdan v Rossijskoj Federatsii. Hentet 23. juni 2020 fra http://kremlin.ru/acts/bank/38016/page/1 